\title{
Increasing Lump Ores Proportion in Blast Furnace Based on the High-temperature Interactivity of Iron Bearing Materials
}

\author{
Shengli WU, Hongliang HAN, Haifa XU, Hongwei WANG and Xiaoqin LIU \\ School of Metallurgical and Ecological Engineering, University of Science and Technology Beijing, Beijing 100083 China. \\ E-mail: liangzi801116@yahoo.com.cn
}

(Received on November 18, 2009; accepted on February 15, 2010)

\begin{abstract}
In this work, the feasibility of increasing lump ores proportion in blast furnace (BF for short) was investigated. The results showed: (1) Not only the physical and chemical properties, but also the metallurgical properties of lump ores, such as the reducibility, thermal decrepitation properties and softening properties, were not worse than those of the pellets, so the BF production would not be influenced greatly when the pellets were replaced by lump ores. (2) The own softening and melting properties of the lump ores (pellets) were dramatically improved by interaction between sinters and lump ores (pellets) found in the experiments, while there was no obvious interaction between lump ores and pellets, pellets and pellets, lump ores and lump ores. The interaction occurred with the contact of burden as in BF, and the main reaction product was $\mathrm{CaFeSiO}_{4}$. Except temperature, the reaction was influenced by the chemical composition, micro-structure and contact conditions, and so on. (3) The softening and melting properties of the integrated furnace charge were improved, and the high-temperature interactivity of iron bearing materials was enhanced when the proportion of lump ores increased and the proportion of pellets decreased, for the reactivity of the lump ore was stronger than that of the pellets. (4) Furthermore, the collocation pattern of lump ores and ratio between lump ores was optimized according to interaction. When the proportion of lump ores was up to $23 \%$ at the excellent collocation pattern and appropriate ratio, the burdens still conformed to the requirements of ironmaking.
\end{abstract}

KEY WORDS: blast furnace; sinter; natural lump ores; pellets; interaction; reaction mechanism; burden structure.

\section{Introduction}

High grog ratio, which will enhance the indirect reduction in upper part of blast furnace, decrease the fuel ratio and improve the soft and melting behavior of iron bearing materials by increasing permeability of burden bed, is considered to be good for BF production in traditional ironmaking theories. ${ }^{1-3)}$ However, the price of pellets, one kind of grog, is much higher than that of natural lump ores, and the producing process of sinter and pellet is energy consumption and environmental pollution. Apparently, from the viewpoint of equipment investment, energy consumption, resource security and environment protection, high proportion of natural lump ore with high grade should be used for BF production.

Although lots of benefits will be brought with the grog ratio decreasing, lump ore will bring some problems, such as thermal decrepitation, endothermic reaction of crystal water decomposition, poor softening and melting property. ${ }^{4-7)}$ All of these will affect the BF production and cause the difficulty for operation. ${ }^{8-10)}$ Therefore, it is an important research subject for iron-making workers that how to increase the proportion of lump ore with no or a little effect on blast furnace production.

In this work, the physical and chemical properties, metal- lurgical properties, and high-temperature reactivity of iron bearing materials were researched. Besides, the softening and dropping properties of burden with different proportions of lump ore were researched. The behavior of different iron bearing materials and integrated burden in lumpy zone, cohesive zone and dropping zone was studied, and technical theory for optimization of burden structure with lump ore proportion increasing was discussed. All of these supplied theoretical basis and technical support for the increase of lump ore proportion in $\mathrm{BF}$, and the theory was verified through the production practice.

\section{Characteristics of Iron Bearing Materials}

At present, sinters, pellets and the natural lump ores are the main iron bearing materials for Chinese BF. The sinter S-A with high basicity from Chinese large-scale iron and steel industry, two kinds of Brazil pellets P-A and P-B, three kinds of Australia lump ores L-A, L-B and L-C, and lump ore L-D (Hainan lump ore)from China to balance basicity were studied in this experiment.

\subsection{Physical and Chemical Properties of Iron Bearing Materials}

Chemical compositions of BF iron bearing materials are 
shown in Table 1. With the chemical composition of the imported pellets compared with that of natural lump ores, it is found that the difference of iron grade and gangue content is not large, while the $\mathrm{S}$ and $\mathrm{P}$ content of the imported lump ores are slightly higher than that of Brazil pellets, however, the effect of this on BF operation is minimal. Moreover, the large decrease of carbonate in the natural lump ores will reduce negative effects on the reducibility and the BF permeability. And the low $\mathrm{SiO}_{2}$ content (except Hainan ores) will also reduce the negative effects on BF.

\subsection{Metallurgical Properties of Iron Bearing Materi- als}

In this study, the metallurgical properties of iron bearing materials, such as the reducibility, thermal decrepitation properties and softening properties are measured.

\subsubsection{Experimental Methods}

(1) Reducibility

In this study, the test on the reducibility of the iron bearing materials is carried out according to the present standard test method in China (GB13241-91). The concrete method is as follows. Firstly, the sample after drying was put into the reaction tube with the diameter as $75 \mathrm{~mm}$, and the weight of the sample is $500 \mathrm{~g}$, the particle size is 10-12.5 mm (the equipment is shown in Fig. 1). Secondly, the temperature raised from the room temperature to $900^{\circ} \mathrm{C}$ in $120 \mathrm{~min}$ with pure nitrogen. Then, the reducing gas with the flow rate $15 \mathrm{~L} / \mathrm{min}$ was pumped into the reaction tube (the reducing gas is composed of $30 \% \mathrm{CO}$ and $70 \% \mathrm{~N}_{2}$ ), and the sample was reduced in the constant temperature for $180 \mathrm{~min}$. Lastly, the weight of sample after reduced was recorded, and the reduction index of the iron bearing materials was calculated, and the formula is as follows:

Table 1. Chemical composition of the iron bearing materials (wt \%).

\begin{tabular}{|c|c|c|c|c|c|c|c|c|c|c|}
\hline Reference & $\mathrm{TFe}$ & $\mathrm{FeO}$ & $\mathrm{CaO}$ & $\mathrm{SiO}_{2}$ & $\mathrm{Al}_{2} \mathrm{O}_{3}$ & $\mathrm{MgO}$ & $\mathrm{TiO}_{2}$ & $\mathrm{P}_{2} \mathrm{O}_{5}$ & $\mathrm{~S}$ & $\mathrm{MnO}$ \\
\hline S-A & 58.42 & 8.33 & 8.70 & 4.80 & 1.65 & 1.92 & 0.08 & 0.120 & 0.010 & 0.32 \\
\hline P-A & 66.01 & 0.67 & 2.68 & 2.36 & 0.63 & 0.09 & 0.05 & 0.056 & 0.005 & 0.13 \\
\hline P-B & 66.85 & 0.30 & 1.61 & 2.32 & 0.82 & 0.17 & 0.03 & 0.076 & 0.006 & 0.12 \\
\hline L-A & 64.41 & 0.40 & 0.01 & 2.60 & 1.26 & 0.05 & 0.01 & 0.144 & 0.016 & 0.48 \\
\hline L-B & 64.34 & 0.48 & 0.11 & 2.18 & 1.44 & 0.15 & 0.03 & 0.151 & 0.019 & 0.26 \\
\hline L-C & 63.28 & 0.53 & 0.01 & 2.46 & 1.24 & 0.05 & 0.02 & 0.116 & 0.023 & 0.10 \\
\hline L-D & 56.87 & 1.83 & 0.36 & 14.42 & 0.53 & 0.12 & 0.09 & 0.048 & 0.278 & 0.10 \\
\hline
\end{tabular}

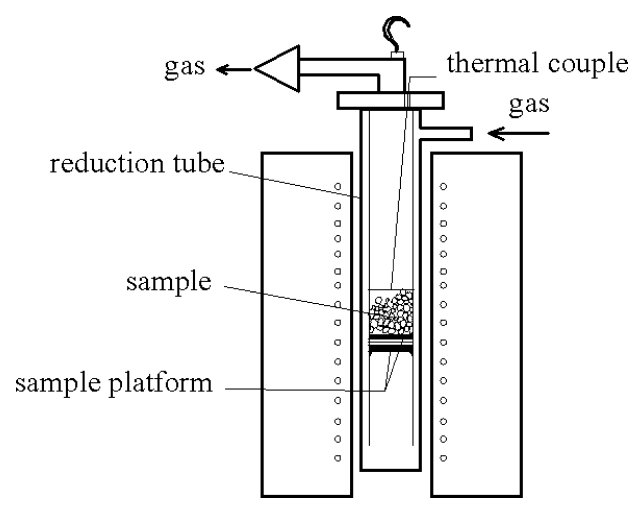

Fig. 1. The test equipment of reducbility.

$$
\mathrm{RI}=\frac{0.11 \mathrm{~B}}{0.43 \mathrm{~A}}+\frac{\mathrm{M} 1-\mathrm{Me}}{0.43 \mathrm{~A} \times \mathrm{Mo}} \times 100(\%)
$$

Where: Mo is the weight of sample (g), M1 is the weight of sample before reduced $(\mathrm{g}), \mathrm{Me}$ is the weight of sample after reduced for $180 \mathrm{~min}(\mathrm{~g}), \mathrm{A}$ is the total iron content of sample before reduced (\%), B is the $\mathrm{FeO}$ content of sample before reduced.

\section{(2) Thermal Decrepitation}

According to the standard ISO8371, the thermal decrepitation index (DI) of the iron bearing material was measured. The equipment is the same as that of the reducibility. The concrete steps are as follows. Firstly, the temperature of the furnace raised from the room temperature to $700^{\circ} \mathrm{C}$ in $30 \mathrm{~min}$, and keep the constant temperature. Secondly, the pure nitrogen with the flow rate $15 \mathrm{~L} / \mathrm{min}$ was pumped into the furnace, and the $500 \mathrm{~g}$ sample after drying was put into the furnace with the particle 20 to $25 \mathrm{~mm}$, heated for $30 \mathrm{~min}$ in the constant temperature. Lastly, the sample after tested was screened with the standard screen, and the percentage of the sample with the particle size less than $6.3 \mathrm{~mm}$ was taken as the DI.

\section{(3) Softening Properties}

The softening properties of the iron bearing materials are measured with the infrared furnace (shown in Fig. 2). The concrete steps are shown as follows. Firstly, the iron bearing materials after reduction are ground to less than 100 mesh and extruded into a cylindrical cake sample, then positioned in experimental stove. The size of the cake is $\phi 8 \mathrm{~mm} \times \mathrm{h} 5 \mathrm{~mm}$. Secondly, with the pure nitrogen, the samples was heated to the designated temperature in $10 \mathrm{~min}$, and keep the constant temperature for $20 \mathrm{~min}$, then the temperature decreased to the room temperature. Lastly, the volume shrinkage of the sample can be measured and calculated with adopting the mercury exhaust volume measurement device. The volume shrinkages of the sample at different temperatures are measured respectively, then the softening start temperature and the softening interval are worked out with interpolation method or extrapolation method. The temperature at which the volume shrinkage is $10 \%$ is defined as the softening start temperature, and the temperature at which the volume shrinkage is $30 \%$ is defined as the softening end temperature. The temperature difference between these is defined as the softening interval.

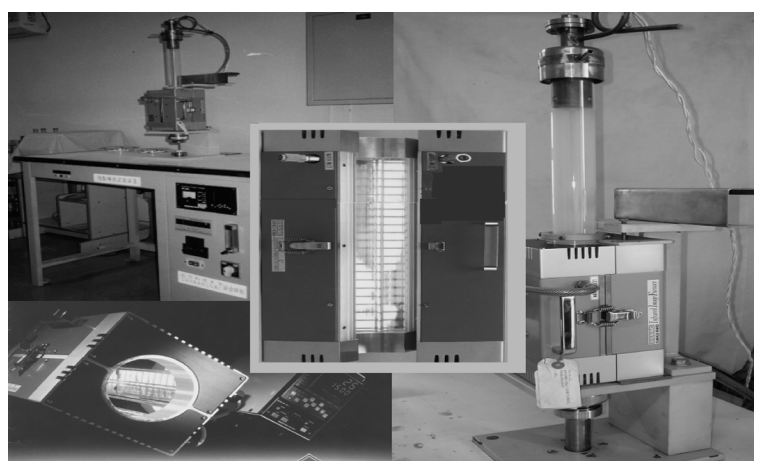

Fig. 2. The high temperature infrared test equipment. 


\subsubsection{Results and Discussions}

The metallurgical properties of iron bearing materials, such as the reducibility, thermal decrepitation properties and softening properties are compared in Table 2.

From the test results of reducibility, the RI of sinter is relatively high, and this is according to the excellent hightemperature metallurgical properties of sinter with high basicity; the RIs of two kinds of pellets with basicity are relatively low; the RIs of Australia lump ores are different, but they are higher than those of pellets, especially RI of L-C with high reducibility is higher than that of sinter; the reducibility of Hainan lump ore to balance basicity is relatively low, but it is slightly higher than that of two pellets. Hence, the traditional view that lump ores have less reducibility is unilateral. Actually, the reducibility of Australia lump ore is at least a little higher than that of Brazil pellets. Therefore, there is no need to be worried about that part of pellets replaced by the lump ore will affect the reduction of BF burden.

It can be seen from the thermal decrepitation results of lump ores that the DIs of Australia lump ores are relatively high, while there is no decrepitation on Hainan ore. But the DI $(-6.13 \mathrm{~mm})$ of L-B with higher DI is still below $6.2 \%$, much lower than the proportion of powder generated from low temperature reduction degradation of sinters and reduction expansion of pellets. The smooth operation of BF would not be influenced by the thermal decrepitation of lump ore. So the ratio of lump ores should not be prevented increasing in BF for the thermal decrepitation.

From the experiment results of softening properties, the softening properties of sinter with high basicity is the best, and the pellets are relatively poor, but a little better than that of lump ores (except Hainan lump ore). The lump ores possess relatively low softening start temperature and wide softening interval, which is according to the traditional recognition. ${ }^{11,12)}$ However, compared with Brazil pellets, the natural lump ores has the condition of narrow softening interval. It is not true that the softening interval of lump ores must be wider than that of pellets. Therefore, with part of pellets replaced by lump ores, the softening properties will not change obviously.

In a word, not only the physical and chemical properties, but also the metallurgical properties of the lump ores, such as reducibility, thermal decrepitation properties and softening properties, are not worse than those of the pellets, so it will not change BF operation obviously that some pellets are replaced by lump ore.

Table 2. Metallurgical properties of iron bearing materials

\begin{tabular}{|c|c|c|c|c|c|}
\hline \multirow{2}{*}{ Reference } & $\begin{array}{c}\text { Reduction index } \\
(\mathrm{RI})\end{array}$ & $\begin{array}{c}\text { Thermal decrepitation index } \\
\text { DI(-6.13mm) }\end{array}$ & $\begin{array}{c}\text { Softening } \\
\text { start } \\
\text { temperature }\end{array}$ & $\begin{array}{c}\text { Softening } \\
\text { end } \\
\text { temperature }\end{array}$ & $\begin{array}{c}\text { Softening } \\
\text { interval }\end{array}$ \\
\cline { 2 - 6 } & $\%$ & $\%$ & ${ }^{\circ} \mathrm{C}$ & ${ }^{\circ} \mathrm{C}$ & ${ }^{\circ} \mathrm{C}$ \\
\hline S-A & 81.2 & --- & 1208 & 1305 & 97 \\
\hline P-A & 67.4 & --- & 1030 & 1256 & 226 \\
\hline P-B & 68.6 & --- & 1033 & 1258 & 225 \\
\hline L-A & 70.7 & 4.93 & 1016 & 1218 & 202 \\
\hline L-B & 73.4 & 6.16 & 995 & 1252 & 257 \\
\hline L-C & 82.3 & 5.46 & 1034 & 1319 & 285 \\
\hline L-D & 68.9 & 0 & 1006 & 1144 & 138 \\
\hline
\end{tabular}

\section{Research on High-temperature Interaction of Iron Bearing Materials}

For the difference of the chemical composition and the composition structure, the metallurgical properties of sinter, pellets and lump ores are different. ${ }^{13-15)}$ There is qualitative knowledge that the disadvantage can be conquered with the collocation of burden, such as the softening start temperature of acidic burden is too low and the temperature interval is too wide, the sinter with high basicity is difficult to melt and drop. ${ }^{16,17)}$ However, there are still some questions to be solved in the traditional iron making theory: What is the relation between the softening and melting properties of integrated burden and that of single component? Whether the softening and melting properties of the integrated burden can be concluded according to that of single component? Therefore, in this work, the interaction of iron bearing materials at high temperature was investigated, and the mechanism of the action mode, the influencing factors were studied. All of these provide the theoretical basis and technical measure for the optimization of burden structure.

\subsection{The Interaction between Lump Ore and Sinter}

The softening properties (the method is the same as that in Sec. 2.2.1) of blending burden composed of lump ore and sinter were studied at $1200^{\circ} \mathrm{C}$. The tests were carried out with the proportions of sinter as $0,20 \%, 50 \%, 80 \%$ and $100 \%$. The results are shown in Fig. 3 .

It can be seen from Fig. 1 that three blending burden showed very consistent pattern. The volume shrinkage of the blending burden is positive deviation from the calculated value based on the respective ratio and the volumetric shrinkage at the same temperature. The tests results further confirm that lump ore and sinter interact at high temperature, for the impetus of chemical reaction between the acidic and alkaline material. Besides, the deviation amplitudes of the blending burden are discrepant with different kinds of lump ore, which indicates that the extent of interaction is discrepant between different lump ores and sinter.

\subsection{The Interaction between Pellets and Sinter}

The softening properties (the method is the same as that in Sec. 2.2.1) of blending burden with different proportions of pellets and sinter were studied at $1200^{\circ} \mathrm{C}$. The results are shown in Fig. 4.

It can be seen from Fig. 2 that according to the blending burden composed of pellets and sinter, the volume shrink-

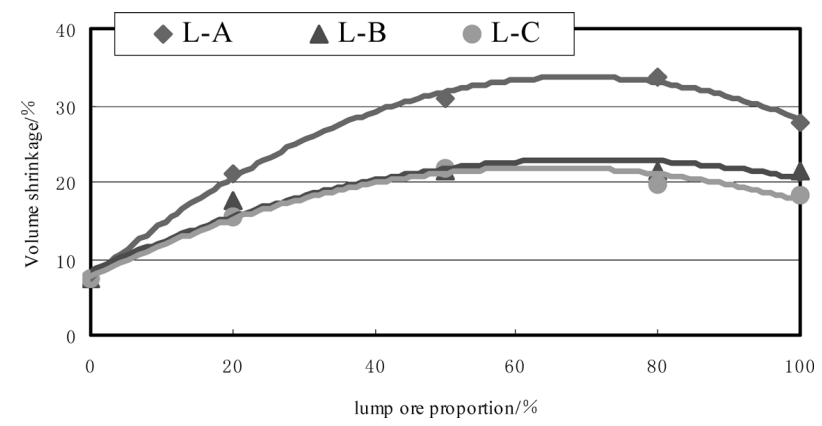

Fig. 3. The softening properties of blending burdens with different lump ore ratios. 


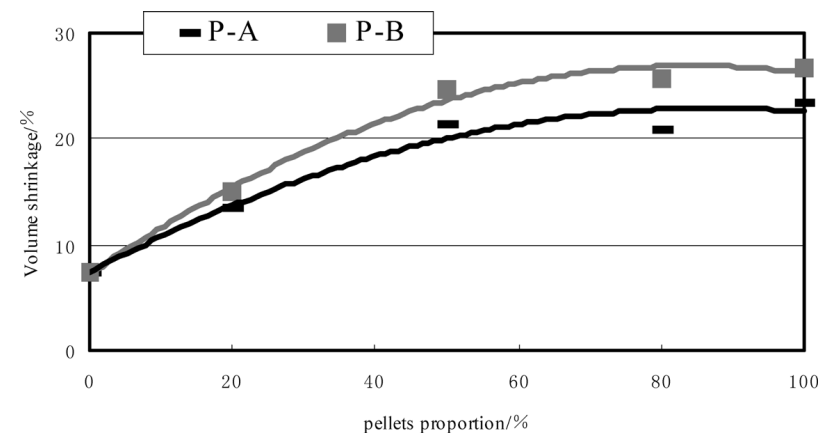

Fig. 4. The softening properties of burdens with different pellet ratios.

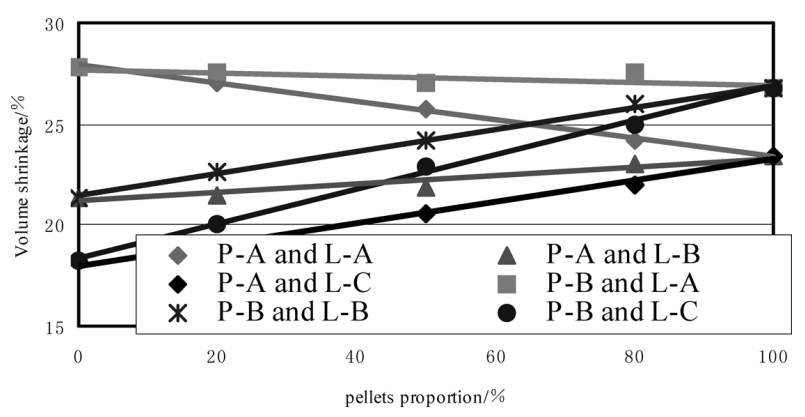

Fig. 5. The softening properties of blending burdens with different pellets and lump ore ratios.

age of the blending burden composed of sinter and pellets with different ratios is also positive deviation from the calculated value based on the respective ratio and the volumetric shrinkage at the same temperature, and the deviation amplitudes are different. This indicates that pellets and sinter interact at high temperature, and the extent of interaction is discrepant between different pellets and sinter.

\subsection{The Interaction between the Pellets and Lump Ore}

The softening properties (the method is the same as that in Sec. 2.2.1) of blending burden with different proportions of pellets and lump ore were studied at $1200^{\circ} \mathrm{C}$. The results are shown in Fig. 5.

It can be seen from Fig. 3 that the volume shrinkage of blending burden composed of pellets and lump ore is almost the same as the calculated value based on the respective ratio and the volumetric shrinkage at the same temperature. Obviously, there is no interaction between the lump ores and pellets at high temperature, but just mixed physically. This is because that the impetus of chemical reaction is in shortage, for the lump ores and pellets are both acidic.

\subsection{The Interaction between Lump Ore and Lump Ore (Pellets and Pellets)}

The softening properties (the method is the same as that in Sec. 2.2.1) of the burden composed of different pellets and the burden composed of different lump ores were studied at $1200^{\circ} \mathrm{C}$. The results are shown in Fig. 6 .

It can be seen from Fig. 4 that there is no interaction between lump ore and lump ore (pellets and pellets) at high temperature. This is because that the properties of lump ores (pellets) are similar.

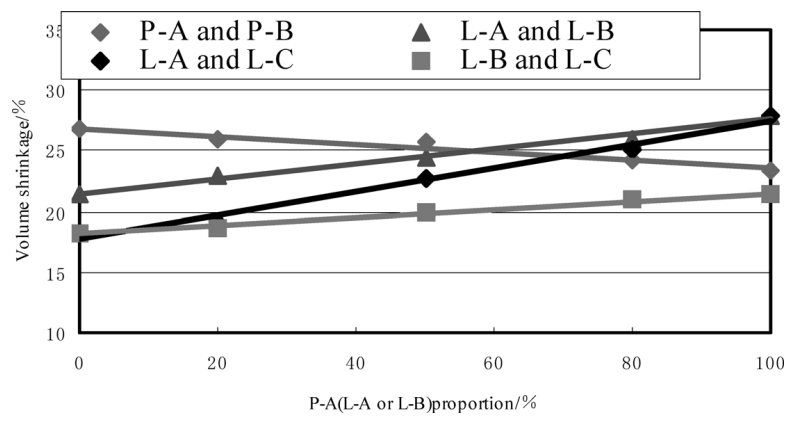

Fig. 6. The softening properties of blending burdens composed of different pellets (lump ores).

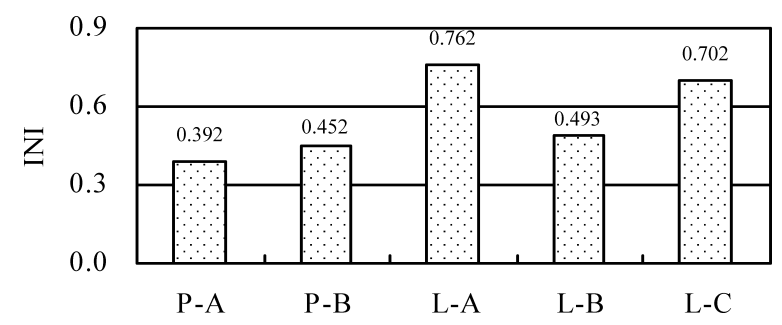

Fig. 7. Interaction indexes between sinter and lump ores (pellets).

\subsection{Evaluation of the High-temperature Interaction between the Iron Bearing Materials}

From the above results, there is no obvious interaction between the pellets and pellets, pellets and lump ores, lump ores and lump ores; The lump ores (pellets) and sinter with high basicity interact at high temperature, and the extent of the interaction between different lump ores (pellets) and sinter are discrepant. ${ }^{18,19)}$ Therefore, the new concept interaction index INI is proposed between lump ore (pellets) and sinter. INI refers to the interaction abilities between lump ore (pellets) and sinter at high temperature and the abilities of integrated burden to improve the poor self-softening properties of lump ore (pellets). The formula of INI is as follows:

$$
\mathrm{INI}=\frac{\eta_{50 \%}-\left(\eta_{\mathrm{S}}+\eta_{\mathrm{L}}\right) / 2}{\left(\eta_{\mathrm{S}}+\eta_{\mathrm{L}}\right) / 2}
$$

Where: INI is the interaction index between the lump ore (pellet) and sinter at high temperature, $\eta_{\mathrm{L}}$ is the volume shrinkage of the lump ore (pellet) at high temperature, $\eta_{\mathrm{S}}$ is the volume shrinkage of sinter at high temperature, and $\eta_{50 \%}$ is the volume shrinkage of the blending burden with the same proportion of sinter and lump ore (pellet).

The INIs of the five kinds of iron bearing materials and sinter are shown in Fig. 7. The INIs of lump ores and sinter were higher than that of pellets and sinter, which means that the interaction between lump ore and sinter can improve the softening properties greatly. There are great differences on the INIs of different lump ores and sinter, and this means the abilities to improve the softening properties are discrepant with different kinds of lump ores.

In order to verify the application of high temperature interaction, the softening properties of the integrated burden of lump ores (pellets) and sinter (the proportion was worked out with the binary basicity of the iron bearing ma- 
Table 3. Softening properties of the integrated burden.

\begin{tabular}{|c|c|c|c|c|c|c|c|}
\hline \multirow[b]{2}{*}{ Reference } & \multicolumn{3}{|c|}{ Respective lump ore(pellets) } & \multicolumn{3}{|c|}{ Integrated burden } & \multirow[b]{2}{*}{$\begin{array}{c}\text { Improvement } \\
\text { Degree }\end{array}$} \\
\hline & $\begin{array}{c}\text { Softening } \\
\text { start } \\
\text { temperature }\end{array}$ & \begin{tabular}{|c|}
$\begin{array}{c}\text { Softening } \\
\text { end } \\
\text { temperature }\end{array}$ \\
\end{tabular} & $\begin{array}{c}\text { Softening } \\
\text { interval }\end{array}$ & $\begin{array}{c}\text { Softening } \\
\text { start } \\
\text { temperature }\end{array}$ & \begin{tabular}{|c|} 
Softening \\
end \\
temperature
\end{tabular} & \begin{tabular}{|c|} 
Softening \\
interval
\end{tabular} & \\
\hline & ${ }^{\circ} \mathrm{C}$ & ${ }^{\circ} \mathrm{C}$ & ${ }^{\circ} \mathrm{C}$ & ${ }^{\circ} \mathrm{C}$ & ${ }^{\circ} \mathrm{C}$ & ${ }^{\circ} \mathrm{C}$ & $\%$ \\
\hline P-A & 1030 & 1256 & 226 & 1153 & 1290 & 137 & 39.38 \\
\hline P-B & 1033 & 1258 & 225 & 1141 & 1265 & 124 & 44.88 \\
\hline L-A & 1016 & 1218 & 202 & 1173 & 1269 & 96 & 52.48 \\
\hline L-B & 996 & 1248 & 252 & 1143 & 1283 & 140 & 44.44 \\
\hline L-C & 1034 & 1319 & 285 & 1144 & 1282 & 138 & 51.58 \\
\hline
\end{tabular}

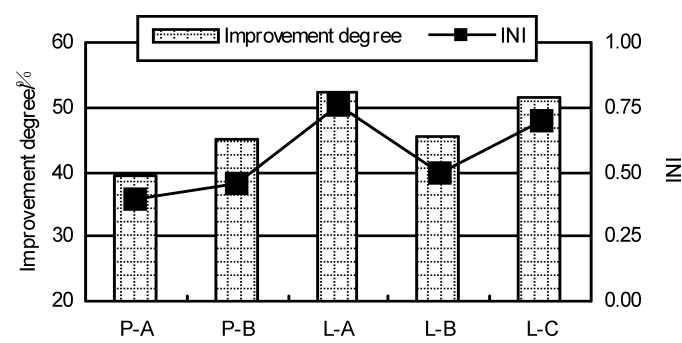

Fig. 8. The effect of INIs on softening temperature interval of integrated burden.

terials as 1.5) are tested. The softening eiqenvalues of the respective burden and integrated burden are shown in Table 3. The influences of INI on the integrated burden softening interval are shown in Fig. 8. The temperature with the volume shrinkage $10 \%$ was defined as the softening start temperature, and the temperature with the volume shrinkage $30 \%$ was defined as the softening end temperature.

\section{Improvement degree \\ $=($ softening interval of integrated burden \\ - softening interval of respective burden) \\ /softening interval of respective burden}

In terms of two pellets, the self-softening properties are similar, but there are some differences on softening properties of integrated burden. The main reason is the difference of high temperature interaction with sinter. The INI of P-B is higher, thus there is relatively obvious improvement on softening temperature interval of integrated burden.

In terms of three lump ores, there is a good corresponding relation between INIs of lump ores and the improvement degree of the integrated burden softening properties. The higher the INI is, the better the softening properties of integrated burden are. Compared with L-A and L-C, the INI of L-B is lower, so the improvement degree of corresponding integrated burden softening properties is lower. Although the softening properties of lump ore L-C is relatively poor and the softening interval is wide, the INI is higher, so the improvement degree of corresponding integrated burden softening properties is higher and better softening properties can be obtained. The results indicate that the high-temperature reactivity of lump ores (pellets) and sinter has great influences on the improvement of the integrated burden softening properties.

\subsection{Mechanism Analysis of the High-temperature In- teraction}

To further investigate mechanism of the interaction between the iron bearing materials, the sample of interaction

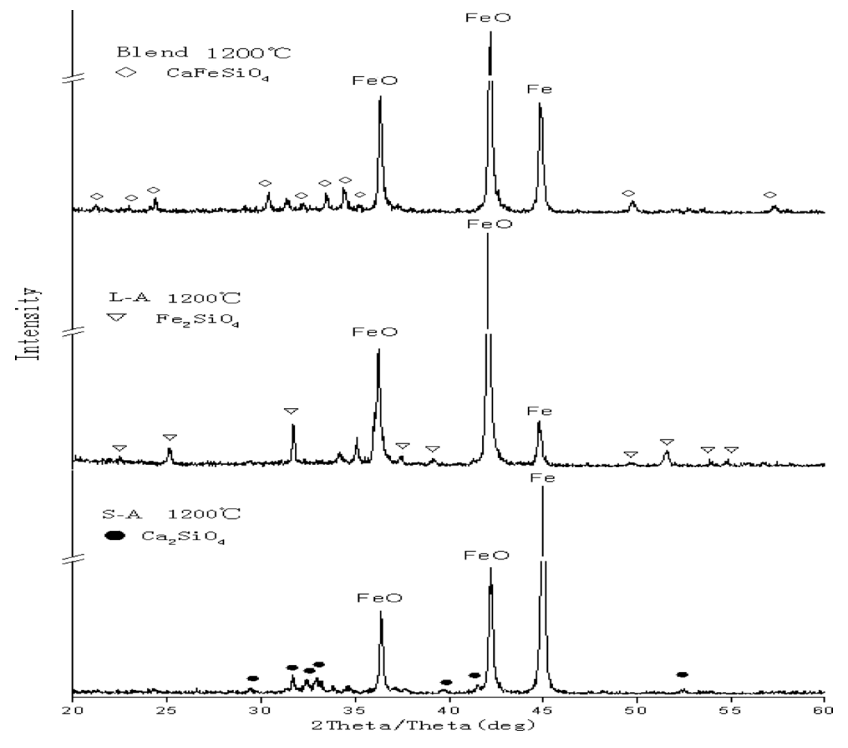

Fig. 9. X-ray diffraction patterns of sinter, lump ore and blending burden.

between lump ore L-A and sinter S-A was analyzed through $\mathrm{X}$-rays diffraction, phase diagram and scanning electron microscope.

\subsubsection{X-rays Diffraction Analysis}

The lump ore L-A, sinter S-A, and the blending burden with the same proportion of L-A and S-A, which was tested at $1200^{\circ} \mathrm{C}$ according to the methods of softening properties test, were analyzed through X-rays diffraction. The diffraction patterns of blending burden and its single component are shown in Fig. 9.

From Fig. 7, no matter sinter S-A, or lump ore L-A, or the blending ore, the main total iron minerals are metal iron and ferrous iron, while the slag minerals are different. In this study, the main slag composition of lump ore is $\mathrm{Fe}_{2} \mathrm{SiO}_{4}$, and the main slag composition of sinter is $\mathrm{Ca}_{2} \mathrm{SiO}_{4}$, while the slag composition of blending burden is different, in which there is no obvious $\mathrm{Fe}_{2} \mathrm{SiO}_{4}$ or $\mathrm{Ca}_{2} \mathrm{SiO}_{4}$ existing in the $\mathrm{X}$-rays diffraction patterns, and the main slag composition is $\mathrm{CaFeSiO}_{4}$. Obviously, the sinter and lump ore are not just mixed physically, while there is interaction at high-temperature zone in $\mathrm{BF}$ and new phase $\mathrm{CaFeSiO}_{4}$ generates from the reaction.

\subsubsection{Phase Diagram Analysis}

The main compositions of reduced lump ore L-A and sinter $\mathrm{S}-\mathrm{A}$ are metal iron, followed by $\mathrm{FeO}, \mathrm{CaO}$ and $\mathrm{SiOB}_{2}$, there are the following reactions among the latter three.

$$
\begin{aligned}
2 \mathrm{FeO}+\mathrm{SiO}_{2} & =2 \mathrm{FeO} \cdot \mathrm{SiO}_{2} \ldots \ldots . . . \\
2 \mathrm{CaO}+\mathrm{SiO}_{2} & =\beta-2 \mathrm{CaO} \cdot \mathrm{SiO}_{2} \ldots \ldots \\
\mathrm{CaO} & +\mathrm{FeO}+\mathrm{SiO}_{2}=\mathrm{CaO} \cdot \mathrm{FeO} \cdot \mathrm{SiO}_{2}
\end{aligned}
$$

Combined with the X-rays diffraction, the main slag composition of reduced lump ore L-A is $2 \mathrm{FeO} \cdot \mathrm{SiO}_{2}$ generated from the reaction according to Eq. (1), and that of S-A is $\beta-2 \mathrm{CaO} \cdot \mathrm{SiO}_{2}$ according to Eq. (2), while there is no $\mathrm{CaO} \cdot \mathrm{FeO} \cdot \mathrm{SiO}_{2}$ generated. According to the phase diagram 


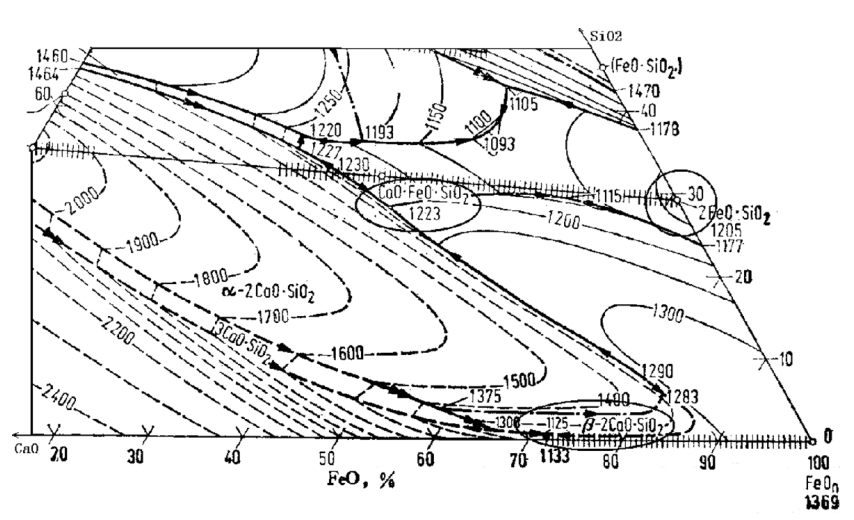

Fig. 10. Phase diagram of $\mathrm{CaO}-\mathrm{SiO}_{2}-\mathrm{FeO}$.

of $\mathrm{CaO}-\mathrm{SiO}_{2 \mathrm{~B}}-\mathrm{FeO}$ (Fig. 10), ${ }^{20)}$ the melting temperature of $2 \mathrm{FeO} \cdot \mathrm{SiO}_{2}$ is lower, while that of $\beta-2 \mathrm{CaO} \cdot \mathrm{SiO}_{2}$ is higher.

However, according to the results of $\mathrm{X}$-rays diffraction, There is new phase $\mathrm{CaO} \cdot \mathrm{FeO} \cdot \mathrm{SiO}_{2}$ generated in blending burden, and this indicates that the lump ore L-A and sinter S-A really interact at high temperature. Besides, from the phase diagram of $\mathrm{CaO}-\mathrm{SiO}_{2}-\mathrm{FeO}$, the melting temperature of slag phase $\mathrm{CaO} \cdot \mathrm{FeO} \cdot \mathrm{SiO}_{2}$ is lower than that of $\beta$ $2 \mathrm{CaO} \cdot \mathrm{SiO}_{2}$, while higher than that of $2 \mathrm{FeO} \cdot \mathrm{SiO}_{2}$, and this indicates the internal cause of the results in Table 3 and Fig. 3 . The cause is that the lump ore L-A and sinter S-A interact at high temperature after reduction, thus the volume shrinkage of blending burden is smaller than that of L-A, while bigger than that of S-A, and the softening temperature is higher than that of L-A, while lower than that of SA.

\subsubsection{Scanning Electron Microscope Analysis}

From the analysis of X-rays diffraction and phase diagram, in the conditions of the complete mixing, there is interaction between lump ore and sinter at high temperature. In order to further investigate that whether the lump ore and sinter interact in the BF contact conditions, another test was carried out. The making method of the sample is as follows. The lump ore L-A and the sinter S-A after reduced was grinded to 100 mesh, and extruded to be a cylindrical cake, with the size as $\phi 8 \mathrm{~mm} \times \mathrm{h} 5 \mathrm{~mm}$. The two cakes were stacked upper and lower, then put into the furnace. With the pure nitrogen, the sample was heated into the designated temperature in $10 \mathrm{~min}$, and keep the constant temperature for $20 \mathrm{~min}$. In this study, the test temperature is $1300^{\circ} \mathrm{C}$. The bonded samples after cooled were carved along the direction of diameter, as shown in Fig. 11. The Secs. 1, 2 and 3 were analyzed with scanning electron microscope. The results of scanning electron microscope analysis are shown in Fig. 12.

It can be seen from Fig. 12 that the SEM picture of the interface between L-A and S-A is very different from that of respective lump ore or sinter. There is diffusion at the interface of the acidic lump ore and sinter with high basicity, because of different chemical composition, microscopic characteristics, and so on. And the gangue components react, with the conditions of thermodynamics and dynamics both satisfied. In fact, at the interface, the generation of the new phase can be observed. From these, With the simulation of contact conditions in BF, the acidic lump ore and

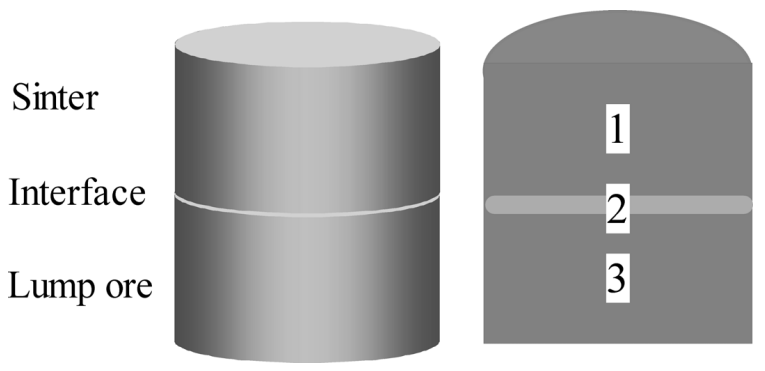

Fig. 11. Schematic diagram of SEM sample.
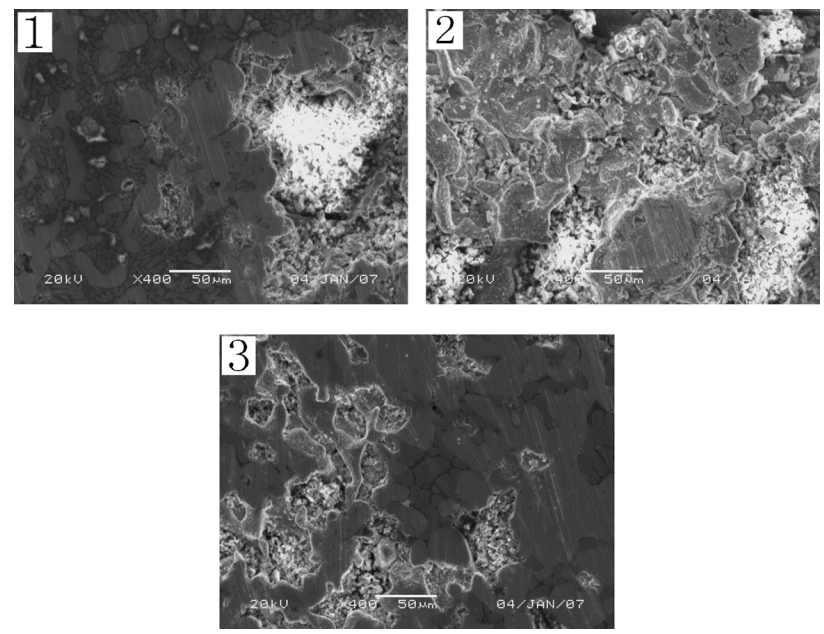

Fig. 12. SEM micrographs of sinter, lump ore and contact surface.

sinter with basicity interact at the interface at high temperature.

\subsubsection{Energy Spectrum Analysis}

The above research indicates that the acidic lump ore and sinter with high basicity interact at high temperature, and the interaction still exists in the conditions of actual contact in BF. However, it is unclear that whether the interaction occurs before the softening of lump ore and sinter, or after the softening of lump ore and before the softening of sinter, or after the softening of lump ore and sinter. Therefore, the conditions of interaction were further tested in this study. The making method of the sample in this part is the same as that in Sec. 3.6.3, while the test temperature is respectively $950^{\circ} \mathrm{C}, 1150^{\circ} \mathrm{C}$ and $1300^{\circ} \mathrm{C}$. The bonded samples after cooled were carved along the direction of diameter, grinded and polished. Then the major elements at the interface were scanned. The results are shown in Fig. 13.

From Fig. 13, the elements diffusion at the interface of lump ore and sinter are not obvious at $950^{\circ} \mathrm{C}$, and it can be inferred that there is no interaction or the interaction is not obvious. At $1150^{\circ} \mathrm{C}$, the diffusion of $\mathrm{Si}$ and $\mathrm{Al}$ is relatively obvious, while there is a little Ca diffusion and the diffusion of $\mathrm{Mg}$ is not obvious. From this, it can be inferred that the interaction exists in this condition, while the reaction degree is not very high. At $1300^{\circ} \mathrm{C}$, the diffusion of $\mathrm{Ca}, \mathrm{Si}$, $\mathrm{Al}$ and $\mathrm{Mg}$ are all obvious, and it can be inferred that the reaction degree is high.

Combined with the softening properties of acidic lump ore and sinter with high basicity, at relatively low temperature (before the softening of lump ore and sinter), the diffu- 


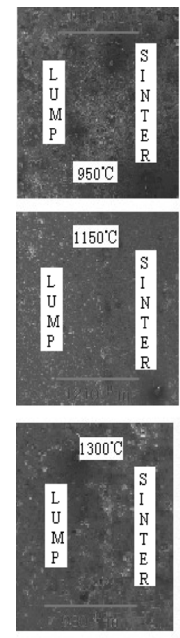

grey file
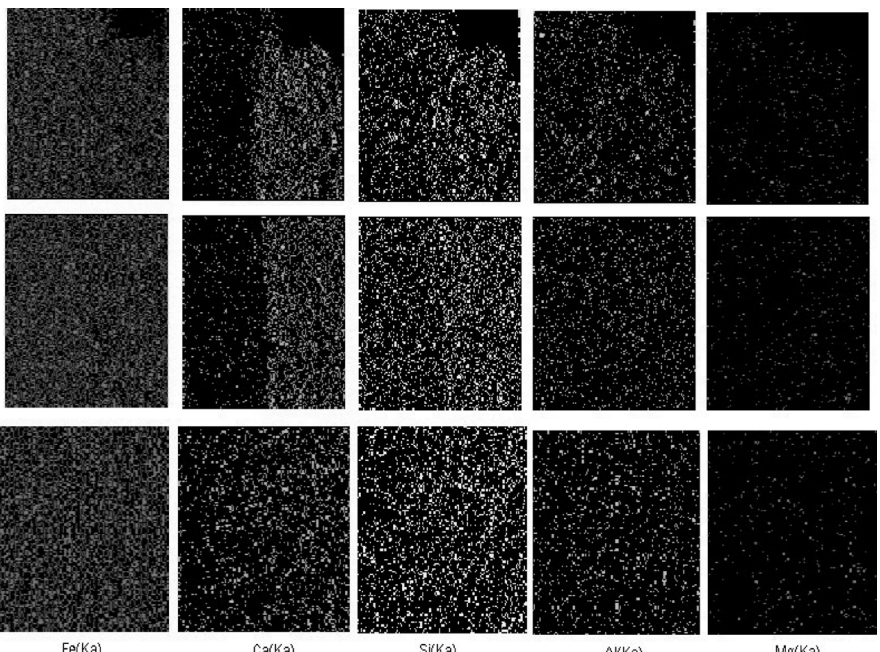

Fig. 13. Elements distribution of contact surface at different temperature.

sion is relatively slow and the interaction hardly occurs. When the temperature rises to a extent, the interaction begin to occur, at which the softening of lump ore occurs and the softening of sinter does not occur. With the temperature further rising and the softening of lump ore and sinter occurring, the conditions of contact, diffusion and reaction are more sufficient, and there is strong interaction between lump ore and sinter.

\subsection{Analysis on the Influencing Factors of the High- temperature Interaction}

The chemical compositions of lump ore and sinter are very different (especially the content of $\mathrm{CaO}$ and $\mathrm{SiO}_{2}$ ), and the micro-structure is different, thus the interaction is inevitable at high temperature. The degree of reaction between different lump ore and sinter are discrepant. Except temperature, the influencing factors of the interaction include the following aspects.

(1) Chemical compositions. It is the decisive factor of the interaction between the iron bearing materials. The reactive substance is directly related with the reaction impetus, especially the $\mathrm{SiO}_{2}$ content, which has great influence on the softening properties of the iron bearing materials. Generally speaking, the higher the $\mathrm{SiO}_{2}$ content is, the larger the reaction impetus is, and the stronger the interaction between lump ore and sinter is. Except $\mathrm{SiO}_{2}$, the $\mathrm{CaO}$ content is another important influencing factor.

(2) Micro-structure. With the chemical compositions influencing the impetus of the reaction, the micro-structure influences the diffusion conditions of the reactive substance. Generally speaking, the looser the micro-structure is, the larger the porosities are, the easier the diffusion of reactive substance to the interface is, the faster the reaction speed is, and the stronger the interaction is.

(3) Contact conditions. In the volume shrinkage curve of blending burden with different proportions, the peak value occurs when the lump ore proportion is $50 \%$. It indicates that just considering reactivity, the contact condition is the best when the ratio of lump ore and sinter is $1: 1$.

Conclusively, the lump ore (pellets) and sinter interact at high temperature in $\mathrm{BF}$, and the poor softening properties of the lump ore (pellets) can be improved. The reaction can occur with the contact conditions in $\mathrm{BF}$, and the major reaction product is $\mathrm{CaFeSiO}_{4}$. Except the temperature, the interaction is influenced by the chemical compositions, microstructure, and contact conditions, and so on. The high-temperature reactivity of lump ores are higher than that of pellets. Thus with the increase of the lump ore proportion and the decrease of the pellets proportion, the high-temperature interaction can be enhanced, and the softening properties of integrated burden can be more improved. The reactivity of different lump ore is discrepant, as a result, in the conditions of that the chemical compositions and other metallurgical properties are similar, the lump ores should be selected and used more, which interacts with sinter strongly, and the softening properties of the integrated burden with this can be more improved.

\section{The Softening and Dropping Properties of the Inte- grated Burden with Different Lump Ore Propor- tions}

Based on the above research, according to the experimental material conditions, six burden structures with different lump ore proportions and collocation patterns were designed. The softening and dropping properties were studied and the technical principles of optimization of the burden structure with the lump ores proportion increase were discussed. This provide basic information for increasing the lump ore proportion in BF.

Six design schemes of burden structure are shown in Table 4. The results of softening and dropping properties are shown in Table 5. The total eigenvalue S represents the integral value of pressure difference between the zoom and dropping start temperature, the softening and dropping eigenvalue SD represents the integral value of pressure difference between the softening start temperature and dropping start temperature.

From the results of scheme A, B and C, in the conditions of that all the lump ore proportions were $20 \%$, the sinter and pellets proportion were relatively constant, compared with the pattern of L-A and L-B (scheme A), the softening start temperature $\left(T_{10 \%}\right)$ and the softening end temperature $\left(T_{40 \%}\right)$ of the pattern of L-A and L-C (scheme B) increased, 
Table 4. Designed scheme of ferrous burden structure of BF (\%).

\begin{tabular}{|c|c|c|c|c|c|c|}
\hline Scheme & A & B & C & D & E & F \\
\hline S-A & 73 & 73 & 73 & 73 & 73 & 73 \\
\hline P-A & 2 & 2 & 2 & 5 & 0 & 0 \\
\hline P-B & 5 & 5 & 5 & 5 & 4 & 0 \\
\hline L-A & 12.0 & 11.9 & 0.0 & 9.5 & 13.8 & 16.8 \\
\hline L-B & 7.0 & 0.0 & 12.0 & 0.0 & 0.0 & 0.0 \\
\hline L-C & 0.0 & 7.0 & 7.0 & 5.7 & 8.2 & 9.8 \\
\hline L-D & 1.0 & 1.1 & 1.0 & 1.8 & 1.0 & 0.4 \\
\hline Lump ore proportion & 20 & 20 & 20 & 17 & 23 & 27 \\
\hline
\end{tabular}

Table 5. Results of melting-dropping properties.

\begin{tabular}{|c|c|c|c|c|c|c|c|c|c|c|}
\hline \multirow{3}{*}{ Scheme } & \multicolumn{1}{|c|}{$\begin{array}{c}\text { Softening properties } \\
\text { simulating in } \mathrm{BF}\end{array}$} & \multicolumn{8}{|c|}{ Melting and dropping properties } \\
\cline { 2 - 11 } & $\mathrm{T}_{10 \%}$ & $\mathrm{~T}_{40 \%}$ & $\Delta \mathrm{T}_{\mathrm{A}}$ & $\mathrm{T}_{\mathrm{S}}$ & $\mathrm{T}_{\mathrm{d}}$ & $\Delta \mathrm{T}_{\mathrm{B}}$ & $\Delta \mathrm{T}$ & $\Delta \mathrm{P}_{\max }$ & $\mathrm{S}$ value & SD value \\
\cline { 2 - 11 } & ${ }^{\circ} \mathrm{C}$ & ${ }^{\circ} \mathrm{C}$ & ${ }^{\circ} \mathrm{C}$ & ${ }^{\circ} \mathrm{C}$ & ${ }^{\circ} \mathrm{C}$ & ${ }^{\circ} \mathrm{C}$ & ${ }^{\circ} \mathrm{C}$ & $\mathrm{Pa}$ & $\mathrm{kPa} \cdot{ }^{\circ} \mathrm{C}$ & $\mathrm{kPa}{ }^{\circ} \mathrm{C}$ \\
\hline $\mathrm{A}$ & 1067 & 1195 & 128 & 1328 & 1408 & 80 & 341 & 1400 & 27.52 & 133.64 \\
\hline $\mathrm{B}$ & 1087 & 1203 & 116 & 1372 & 1410 & 38 & 323 & 1320 & 19.30 & 114.47 \\
\hline $\mathrm{C}$ & 1055 & 1170 & 115 & 1301 & 1398 & 97 & 343 & 1510 & 32.80 & 145.62 \\
\hline $\mathrm{D}$ & 1105 & 1221 & 116 & 1305 & 1386 & 81 & 281 & 1280 & 28.24 & 115.37 \\
\hline $\mathrm{E}$ & 1090 & 1188 & 98 & 1353 & 1383 & 30 & 293 & 1140 & 9.38 & 90.81 \\
\hline $\mathrm{F}$ & 1069 & 1183 & 114 & 1356 & 1390 & 34 & 321 & 1360 & 15.71 & 112.36 \\
\hline
\end{tabular}

and the softening temperature interval $\left(\Delta T_{\mathrm{A}}\right)$ decreased; The temperature at which pressure difference $\left(T_{\mathrm{s}}\right)$ began to zoom increased, the dropping start temperature $\left(T_{\mathrm{d}}\right)$ increased, and the dropping temperature interval $\left(\Delta T_{\mathrm{B}}\right)$ decreased. The softening and dropping temperature interval $(\Delta T)$ decreased, the most pressure difference $\left(\Delta P_{\max }\right)$ decreased, The total eigenvalue $\mathrm{S}$ and softening and dropping eigenvalue SD decreased. In the pattern of L-B and L-C (scheme C), the softening start temperature and the softening end temperature decreased, the temperature at which pressure difference began to zoom decreased, the dropping start temperature decreased, the dropping temperature interval increased, the most pressure difference increased, the total eigenvalue $\mathrm{S}$ and softening and dropping eigenvalue $\mathrm{SD}$ increased. All of these mean that the softening and dropping properties of burden with the pattern of L-A and L-C (scheme B) are relatively good. The following is the burden with the pattern of L-A and L-B (scheme A). The softening and dropping properties of burden with the pattern of L-B and L-C (scheme C) are relatively bad. The discrepancy on the high-temperature reactivity of different lump ores is the main cause of the above results. Among three lump ores, the high-temperature reactivity of L-A and $\mathrm{L}-\mathrm{C}$ is relatively strong, and that of L-B is relatively weak. Therefore, the softening and dropping properties of scheme $\mathrm{B}$ are the best, while in scheme $\mathrm{C}$, the softening and dropping properties are relatively the worst, for the proportion of L-B with poor softening and dropping properties is relatively high.

Based on the above experiment, the pattern (L-A and L$\mathrm{C}$ ), in which the burden softening and dropping properties are the best, is chosen to be tested with different lump ores proportions. With the lump ore proportion increasing from 17 to $23 \%$ (scheme D, B and E), the softening temperature interval gradually decreased, the softening properties were improved, the dropping temperature interval decreased, and the total eigenvalue $\mathrm{S}$ and softening and dropping eigenvalue SD decreased. All of these indicate that the softening and dropping properties are improved with the lump ores proportion increasing, instead of getting worse. The main
Table 6. The economic and technical indexes in BF with different burden structure and lump ores proportions.

\begin{tabular}{|c|c|c|c|c|}
\hline Scheme & Unit & P-1 & P-2 & P-3 \\
\hline S-A & $\%$ & 70 & 70 & 70 \\
\hline P-A & $\%$ & 5 & 5 & 2 \\
\hline P-B & $\%$ & 5 & 5 & 5 \\
\hline L-A & $\%$ & 11.8 & 11.5 & 13.2 \\
\hline L-B & $\%$ & 7.3 & 0 & 0 \\
\hline L-C & $\%$ & 0 & 7.5 & 8.9 \\
\hline L-D & $\%$ & 0.9 & 1.0 & 0.9 \\
\hline Lump ores proportion & $\%$ & 20 & 20 & 23 \\
\hline Productivity & $\mathrm{t} / \mathrm{m}^{3} \cdot \mathrm{d}$ & 2.318 & 2.385 & 2.433 \\
\hline Coke ratio & $\mathrm{kg} / \mathrm{t}$ & 298.88 & 297.74 & 294.93 \\
\hline Coal ratio & $\mathrm{kg} / \mathrm{t}$ & 200.13 & 199.81 & 200.62 \\
\hline Fuel ratio & $\mathrm{kg} / \mathrm{t}$ & 499.01 & 497.54 & 495.55 \\
\hline Permeability (K value) & --- & 2783 & 2779 & 2769 \\
\hline
\end{tabular}

reason is that the increase of two lump ores with strong high-temperature reactivity and decrease of the pellets with poor reactivity is helpful to improve the poor softening properties of the lump ore and pellets. With the lump ore proportion increasing from 23 to $27 \%$, the softening start temperature decreased, the softening temperature interval increased, the softening properties got worse, the dropping temperature interval increased, the softening and dropping temperature interval increased, and the total eigenvalue $\mathrm{S}$ and softening and dropping eigenvalue SD increased. But the softening and dropping properties of the integrated burden were still relatively good, even better than that of the burden with $20 \%$ lump ores. From this, when the lump ores proportion is $27 \%$, although the burden structure is competent, its capacities of improving the softening and dropping properties of the integrated burden are deficient to some extent.

In conclusion, through the test on the softening and dropping properties of the integrated burden, it is validated that the high-temperature interactivity not only can optimize the collocation pattern and adjust the proportions of different lump ores, but also can guide the increase of lump ores proportion in $\mathrm{BF}$.

\section{The Production Practice of Increasing the Lump Ore Proportion in BF}

According to the above research results, the production practice of increasing lump ores proportion was carried out in certain Chinese large BF. The results are shown in Table 6.

With the lump ore proportion $20 \%$ and the proportion of sinter and pellets constant, the economic and technical indexes of the collocation pattern L-A and L-C are better than those of the pattern L-A and L-B. And the indexes get better instead of getting worse with the lump ores proportion increasing to $23 \%$ in the collocation pattern L-A and L-C. All of these are according to the results in the lab, and further validate the significance of high-temperature interaction in the optimization of burden structure and the increase of lump ores proportion in BF.

\section{Conclusions}

(1) No matter the physical and chemical properties, or the metallurgical properties, such as reduction properties, 
the thermal decrepitation properties and the softening properties, lump ores are not worse than those of pellets. Therefore, with the pellets replaced by lump ore, there is no negative influence on the BF.

(2) There is no obvious interaction between the lump ores and pellets, pellets and pellets, and lump ore and lump ore. There is high-temperature interaction between the lump ores (pellets) and sinter, and this can improve the poor softening properties of the lump ores and pellets. The stronger the reactivity is, the higher the degree of improvement on the integrated burden softening properties is.

(3) The high-temperature interaction can occur with the burden contact as in $\mathrm{BF}$, and the major production is $\mathrm{CaFeSiO}_{4}$. Except temperature, the reaction is influenced by other factors, such as chemical compositions, microstructure, the contact conditions, and so on.

(4) The high-temperature interactivity of lump ores are higher than that of pellets. The high-temperature interactivity of iron bearing materials will be enhanced and the softening properties of integrated burden will be improved with the lump ores proportion increasing and the pellets proportion decreasing. The high-temperature interactivity of different lump ores are discrepant, and according to this, the collocation pattern of lump ore can be optimized and the proportions of different lump ores can be adjusted.

(5) With the suitable collocation pattern and proportions of different lump ores, when the lump ores proportion increase to $23 \%$ in lab, even to $27 \%$, the softening and dropping properties of integrated burden are still good. The good economic and technical indexes can be achieved in the industrial production with the lump ores proportion $23 \%$ in BF.

\section{REFERENCES}

1) U. S. Yadav, D. N. Jha and B. K. Das: The 5th Ironmaking Conf., Instituto Argentino de Siderurgia, San Nicolas, Argentina, (2005), 371.

2) M. Kato, S. Mizoguchi and K. Tsuzaki: ISIJ Int., 40 (2000), 543.

3) P. L. Hooey, J. Sterneland and M. Hallin: The 1st Int. Meeting on Ironmaking, Iron and Steel Society, Warrendale, P.A., (2001), 24.

4) X. L Wang: Metallurgy of Iron and Steel (The Iron Part), Metallurgical Industry Press, Beijing, (2002), 52.

5) C. D. Zhou: Blast Furnace Ironmaking Technical Manual, Metallurgical Industry Press, Beijing, (2002), 43.

6) H. T. Wang, G. H. Li, X. H. Fan, Z. C. Huang and T. Jiang: Iron Steel (China), 41 (2006), 23.

7) P. F. Nogueira and R. J. Fruehan: Metall. Mater. Trans. B, 35B (2004), 829.

8) P. F. Nogueira and R. J. Fruehan: Metall. Mater. Trans. B, 36B (2005), 583.

9) P. F. Nogueira and R. J. Fruehan: Metall. Mater. Trans. B, 37B (2006), 551.

10) Q. D. Zhou, X. L. Wang and M. X. Xu: Iron Steel (China), 19 (1984), 1.

11) V. J. Ritz, H. A. Kortmann and K. Koch: The 2nd Int. Cong. on the Science and Technology of Ironmaking and 57th Ironmaking Conf., Iron and Steel Society, Warrendale, P.A., (1998), 1635.

12) G. Clixby: Ironmaking Steelmaking, (1986), 169.

13) P. F. Nogueira and R. J. Fruehan: The 2nd Int. Meeting on Ironmaking and the 1st Int. Symp. on Iron Ore, Associação Brasileira de Metalurgia e Materiais, Vitoria, Brazil, (2004), 893.

14) S. Suzuki and K. Suzuki: CAMP-ISIJ, 5 (1992), 1433.

15) X. W. Lv, C. G. Bai, G. B. Qiu, Y. Q. Ou and Y. M. Huang: Iron Steel (China), 42 (2007), 12.

16) S. L. Wu, J. D. Sun, J. X. Du and X. M. Hu: The 4th Metallurgical Engineering Proc., Metallurgical Industry Press, Beijing, (2005), 42.

17) S. L. Wu, H. F. Xu, G. J. Wang, Z. Y. Li, Y. Q. Tian and H. Chen: Iron Steel (China), 29 (2007), 320.

18) S. L. Wu, G. J. Wang, W. Z. Jiang, J. D. Sun and H. F. Xu: Iron Steel (China), 42 (2007), 10.

19) S. L. Wu, H. F. Xu and Y. Q. Tian: The 4th Int. Cong. on the Science and Technology of Ironmaking, Iron and Steel Institute of Japan, Tokyo, Japan, (2006), 197.

20) West German Engineer Institute: Slag Diagrams, Metallurgical Industry Press, Beijing, (1989), 80. 